\title{
Respons Beberapa Tanaman Sayuran Bermikoriza terhadap Dosis P pada Sistem Hidroponik Model Ebb Flow
}

\author{
Derisfha Sri Anggraeni1), Anne Nurbaity²), dan Emma Trinurani Sofyan²) \\ 1)Program Studi Magister Ilmu Tanah, Fakultas Pertanian, Universitas Padjadjaran \\ 2)Departemen Ilmu Tanah dan Sumberdaya Lahan, Fakultas Pertanian Universitas Padjadjaran \\ Jl. Raya Bandung Sumedang Km 21 Jatinangor, Sumedang
}

Korespondensi: derisfha@gmail.com

\begin{abstract}
Hydroponics is one of the urban farming techniques that can be used to improve crop yield. Nowadays, the supply of all nutriens in hydroponics, particulary phosphate only derived from inorganic fertilizers. Application of arbuscular mycorhiza fungi (AMF) as bioagent may help plants to fill its nutrient need, especially phosphate. This study aimed to find out the best concentration of phosphate fertilizer to be applied to the hydroponic Ebb-flow system model. The stage was to test several vegetable plants with various concentrations of phosphorus $(0,20,40,80 \mathrm{ppm})$ on the Ebbflow hydroponic system. Vegetables used were romaine lettuce, red lettuce, and kale. Interaction was found between vegetables and the variety of phosphate concentrations and the root colonization by $A M F$, and phosphate uptake. The AMF applications on the hydroponic Ebb-Flow system model reduced phosphate fertilizer need by 40 ppm (50\%), on red lettuce 0 ppm (100\%), and on kale 20 ppm (25\%). Besides lowered phosphate doses, such applications also increased the plant yield.
\end{abstract}

Keyword: AMF, Hydroponic, Vegetables

\section{PENDAHULUAN}

Penurunan luas lahan akibat konversi lahan terutama lahan pertanian mengakibatkan kesenjangan dalam pemenuhan kebutuhan bahan makanan. Pemenuhan kebutuhan akan produk hasil pertanian memerlukan teknologi dan inovasi. Minimnya lahan pertanian di kota menyebabkan munculnya konsep urban farming. Urban farming merupakan konsep memindahkan pertanian konvensional ke pertanian di perkotaan guna menopang kebutuhan pangan di perkotaan (Natalia et al.,2017). Teknologi budidaya secara hidroponik merupakan salah satu teknik urban farming yang dapat dimanfaatkan dalam pengembangan dan peningkatan hasil tanaman. Teknik produksi tanaman secara hidroponik mampu meningkatkan hasil dan meningkatkan kualitas produk sehingga penggunaan sistem ini meningkat lima kali lipat dalam 10 tahun terakhir pada industri komersial hidroponik (Lee \& Lee, 2015).
Penggunaan sistem hidroponik banyak diaplikasikan untuk tanaman sayuran dan sangat tergantung pada nutrisi hara, cahaya, air sesuai kebutuhan masing-masing tanaman. Salah satu teknik hidroponik sistem Ebb-Flow memiliki keunggulan dalam menyediakan unsur hara dan air secara otomatis. Suplai unsur hara hidroponik berasal dari pupuk anorganik yang memiliki kelemahan yaitu membutuhkan pembiayaan mahal dan tidak ekonomis untuk petani.

Pemanfaatan salah satu agen hayati Fungi Mikoriza Arbuskula (FMA) dapat membantu tanaman dalam pemenuhan unsur hara, terutama unsur P. Fungi Mikoriza Arbuskula merupakan jamur mutualisme yang berasosiasi dengan akar tanaman hampir dengan 90\% tanaman tinggi, termasuk tanaman sayuran. FMA dianggap sebagai natural plant health insurance yang memberikan dampak positif terhadap pertumbuhan, kesehatan tanaman, reklamasi 
lahan, dan alternatif dari penggunaan bahanbahan kimia (Barea, 2000; Beladinna, 2017).

Kangkung (Ipomoea reptans.) meru-pakan tanaman hortikultura yang memiliki potensi pasar yang tinggi dan termasuk kedalam komoditas yang paling banyak diproduksi dan dikonsumsi. Nilai gizi pada kangkung cukup tinggi, seperti vitamin A, B, dan C serta berbagai mieral terutama zat besi yang berguna bagi pertumbuhan badan dan kesehatan (Haryono, 2009; Edi, 2014). Selain kangkung, selada merupakan sayuran yang diminati masyarakat setelah kangkung. Selada mengandung air yang kaya karbohidrat, serat dan protein, dan menyediakan sekitar 15 kalori untuk setiap 100 gramnya. Jumlah kandungan gizi selada adalah Energi $15 \mathrm{kkal}$, Protein 1,2 gr, Lemak 0,2 gr, Karbohidrat 2,9 gr, Kalsium 22 mg, Fosfor 25 mg, Zat Besi 1mg, Vitamin A 540 IU, Vitamin B1 0,04 mg dan Vitamin C 8 mg (Novriani, 2014).

Aplikasi agen hayati FMA dan MHB pada tanaman sayuran dengan sistem hidroponik memiliki nilai tambah yaitu hasil produksi sayuran dan inokulum pupuk hayati. Oleh karena itu, perlu dilakukan penelitian untuk mengetahui konsentrasi $P$ terbaik pada berbagai tanaman sayuran terhadap kolonisasi akar, serapan hara $\mathrm{P}$, serta hasil tanaman terbaik pada Sistem Hidroponik Model EbbFlow.

\section{METODOLOGI}

Bahan-bahan yang digunakan dalam penelitian ini meliputi Fungi Mikoriza Arbuskula (FMA) Glomus sp. dan Gigaspora decipien yang merupakan koleksi Laboratorium Biologi Tanah UNPAD 10 spora $\mathrm{g}^{-1}$, Bacillus mycoides, Bacillus subtilis, Pseudomonas diminuta, Burkholderia gladioli, dan B. cenocepacia yang merupakan koleksi Laboratorium Biologi Tanah Unpad. Selain itu, benih tanaman yang digunakan adalah benih selada Romaine, benih selada merah Varietas
New Red Fire, dan benih kangkung Varietas Bangkok LP-1.

Formulasi unsur hara yang digunakan $\mathrm{CaNO}_{3}$ (Calcium Nitrat), $\mathrm{KNO}_{3}$ (Potasium Nitrat), MKP (Monopotasium Phosphat), $\mathrm{K}_{2} \mathrm{SO}_{4}$ (Potasium Sulphat), $\left(\mathrm{NH}_{4}\right)_{2} \mathrm{SO}_{4}$ (Ammonium Sulphat), $\mathrm{MgSO}_{4}$ (Magnesium sulphat), dan trace elements $(\mathrm{Fe}, \mathrm{Cu}, \mathrm{Mn}, \mathrm{Zn}, \mathrm{B}$, Mo pada $\mathrm{pH}$ $5,8)$. Media tanam yang digunakan yaitu campuran zeolit dan arang sekam (3:1 v/v) (Prafithriasari dan Nurbaity, 2010) dan rockwool.

Pengujian dilakukan dengan Rancangan Petak Terbagi (split plot) Pola Faktorial dengan tiga kali pengulangan di Green House Bandung Utara, Jawa Barat. Peta utama adalah berbagai konsentrasi fosfor $(0,20,40,80 \mathrm{ppm})$ yang terdiri atas empat taraf dan anak petak adalah beberapa tanaman sayuran (selada merah, selada romain, kangkung) dengan FMA dan non FMA yang terdiri atas enam taraf. Diperoleh 24 perlakuan dengan tiga kali ulangan, sehingga total satuan percobaan adalah 72 satuan percobaan.

\section{HASIL DAN PEMBAHASAN}

\subsection{Kolonisasi Akar}

Persentase kolonisasi akar pada Tabel 1 menunjukkan selada romain bermikoriza berpengaruh nyata pada konsentrasi P 20 ppm dan tidak berbeda nyata dengan konsentras $\mathrm{P}$ 0 ppm dan $40 \mathrm{ppm}$. Sedangkan respon tanaman selada merah bermikoriza dan kangkung bermikoriza dengan perlakuan berbagai konsentrasi $\mathrm{P}$ tidak memberikan pengaruh yang berbeda nyata terhadap persentase kolonisasi akar FMA.

Konsentrasi fosfor 0 ppm dan 80 ppm pada tanaman selada romain bermikoriza, selada merah bermikoriza dan kangkung bermikoriza tidak memberikan pengaruh signifikan terhadap kolonisasi akar FMA. Konsentrasi P 20 ppm pada selada romain bermikoriza memberikan pengaruh yang berbeda nyata 
terhadap kolonisasi akar dan tidak berbeda nyata dengan selada merah bermikoriza. Sedangkan pengaruh konsentrasi P 40 ppm pada tanaman selada romain bermikoriza dan selada merah bermikoriza menunjukkan pengaruh signifikan terhadap kolonisasi akar FMA. Tingginya kolonisasi akar tanaman sayuran berkaitan dengan fotosintat dan eksudat akar inang.

Tabel 1 Pengaruh Konsentrasi Fosfor dan Beberapa Tanaman Sayuran terhadap Kolonisasi Akar

\begin{tabular}{|c|c|c|c|}
\hline \multirow[b]{2}{*}{$\begin{array}{c}\text { Konsentrasi } \\
\text { P }\end{array}$} & \multicolumn{3}{|c|}{ Kolonisasi Akar (\%) } \\
\hline & $\begin{array}{l}\text { Selada } \\
\text { Romain }\end{array}$ & $\begin{array}{l}\text { Selada } \\
\text { Merah }\end{array}$ & Kangkung \\
\hline $0 \mathrm{ppm}$ & $\begin{array}{c}97,8 \mathrm{AB} \\
\mathrm{a}\end{array}$ & $\begin{array}{c}94,4 \mathrm{~A} \\
\mathrm{a}\end{array}$ & $\begin{array}{c}95,6 \mathrm{~A} \\
\mathrm{a}\end{array}$ \\
\hline 20 ppm & $\begin{array}{c}100 \mathrm{~B} \\
\mathrm{~b}\end{array}$ & $\begin{array}{c}98,9 \mathrm{~A} \\
\mathrm{ab}\end{array}$ & $\begin{array}{c}88,9 \mathrm{~A} \\
\mathrm{a}\end{array}$ \\
\hline $40 \mathrm{ppm}$ & $\begin{array}{c}98,9 \mathrm{AB} \\
\mathrm{b}\end{array}$ & $\begin{array}{c}100 \mathrm{~A} \\
\mathrm{~b}\end{array}$ & $\begin{array}{c}90,0 \mathrm{~A} \\
\mathrm{a}\end{array}$ \\
\hline 80 ppm & $\begin{array}{c}95,6 \mathrm{~A} \\
\mathrm{a}\end{array}$ & $\begin{array}{c}97,8 \mathrm{~A} \\
\mathrm{a}\end{array}$ & $\begin{array}{c}95,6 \mathrm{~A} \\
\mathrm{a}\end{array}$ \\
\hline $\begin{array}{r}\text { Keterangan : } \mathrm{Ar} \\
\text { be } \\
\text { be } \\
\mathrm{Hu} \\
\mathrm{hu}\end{array}$ & $\begin{array}{l}\text { a yang di } \\
\text { eda nyat } \\
\text { anda Dur } \\
\text { f kecil dil } \\
\text { f kapital l }\end{array}$ & $\begin{array}{l}\text { ti huruf } \\
\text { lenurut } \\
\text { n pada } \\
\text { a ke ara } \\
\text { rah vert }\end{array}$ & $\begin{array}{l}\text { ng sama tida } \\
\text { i lanjut jara } \\
\text { af nyata } 5 \% \\
\text { iorizontal da }\end{array}$ \\
\hline
\end{tabular}

\subsection{Serapan $P$}

Analisis ragam menunjukkan terdapat pengaruh interaksi antara konsentrasi fosfor dengan beberapa tanaman sayuran terhadap serapan $\mathrm{P}$ yang disajikan pada Tabel 2 . Konsentrasi $\mathrm{P}$ pada tanaman selada romain non mikoriza memberikan pengaruh yang berbeda nyata pada konsentrasi P 40 ppm dan tidak berbeda nyata dengan konsentrasi $\mathrm{P} 80$ ppm. Selada romain bermikoriza menunjukkan pengaruh signifikan terhadap serapan $P$ pada konsentrasi P 40 ppm dan 80 ppm.

Pada tanaman selada merah non mikoriza terdapat pengaruh yang berbeda nyata serapan P pada konsentrasi P 80 ppm dan tidak berbeda nyata dengan konsentrasi P $40 \mathrm{ppm}$. Pengaruh konsentrasi P 0 ppm pada tanaman selada merah bermikoriza berpengaruh nyata terhadap serapan P. Tanaman kangkung non mikoriza berpengaruh nyata terhadap serapan $P$ pada konsentrasi $P 80 \mathrm{ppm}$. Pengaruh berbagai konsentrasi $P$ pada tanaman kangkung bermikoriza tidak berbeda nyata terhadap serapan P.

Tabel 2 Pengaruh Konsentrasi Fosfor dan Beberapa Tanaman Sayuran terhadap Kandungan Serapan P

\begin{tabular}{|c|c|c|c|c|c|c|}
\hline \multicolumn{7}{|c|}{ Serapan P (\%) } \\
\hline \multirow[b]{2}{*}{ Konsentrasi P } & \multicolumn{2}{|c|}{ Selada Romain } & \multicolumn{2}{|c|}{ Selada Merah } & \multicolumn{2}{|c|}{ Kangkung } \\
\hline & $\begin{array}{c}\text { Non } \\
\text { Mikoriza }\end{array}$ & Mikoriza & $\begin{array}{c}\text { Non } \\
\text { Mikoriza }\end{array}$ & Mikoriza & Non Mikoriza & Mikoriza \\
\hline $0 \mathrm{ppm}$ & $\begin{array}{c}0,6 \mathrm{AB} \\
\mathrm{ab}\end{array}$ & $\begin{array}{c}0,5 \mathrm{~A} \\
\mathrm{a}\end{array}$ & $\begin{array}{c}0,8 \mathrm{AB} \\
\mathrm{ab}\end{array}$ & $\begin{array}{c}4,1 \mathrm{~B} \\
\mathrm{c}\end{array}$ & $\begin{array}{c}0,4 \mathrm{~A} \\
\mathrm{a}\end{array}$ & $\begin{array}{c}1,0 \mathrm{~A} \\
\mathrm{~b}\end{array}$ \\
\hline $20 \mathrm{ppm}$ & $\begin{array}{c}0,4 \mathrm{~A} \\
\mathrm{a}\end{array}$ & $\begin{array}{c}0,8 \mathrm{~B} \\
\mathrm{~b}\end{array}$ & $\begin{array}{c}0,7 \mathrm{~A} \\
\mathrm{~b}\end{array}$ & $\begin{array}{c}0,8 \mathrm{~A} \\
\mathrm{~b}\end{array}$ & $\begin{array}{c}1,0 \mathrm{~B} \\
\mathrm{c}\end{array}$ & $\begin{array}{c}1,1 \mathrm{~A} \\
\mathrm{c}\end{array}$ \\
\hline $40 \mathrm{ppm}$ & $\begin{array}{c}1,0 \mathrm{C} \\
\mathrm{ab}\end{array}$ & $\begin{array}{c}1,1 \mathrm{C} \\
\mathrm{ab}\end{array}$ & $\begin{array}{c}1,0 \mathrm{BC} \\
\mathrm{ab}\end{array}$ & $\begin{array}{c}1,4 \mathrm{~A} \\
\mathrm{c}\end{array}$ & $\begin{array}{c}0,9 \mathrm{AB} \\
\mathrm{a}\end{array}$ & $\begin{array}{c}1,1 \mathrm{~A} \\
\mathrm{ab}\end{array}$ \\
\hline $80 \mathrm{ppm}$ & $\begin{array}{c}0,8 \mathrm{BC} \\
\mathrm{a}\end{array}$ & $\begin{array}{c}1,1 \mathrm{C} \\
\mathrm{a}\end{array}$ & $\begin{array}{c}1,2 \mathrm{C} \\
\mathrm{a}\end{array}$ & $\begin{array}{c}1,2 \mathrm{~A} \\
\mathrm{a}\end{array}$ & $\begin{array}{c}1,3 \mathrm{C} \\
\mathrm{a}\end{array}$ & $\begin{array}{c}1,3 \mathrm{~A} \\
\mathrm{a}\end{array}$ \\
\hline
\end{tabular}

Keterangan : Angka yang diikuti huruf yang sama tidak berbeda nyata menurut uji lanjut jarak berganda Duncan pada taraf nyata $5 \%$. Huruf kecil dibaca ke arah horizontal dan huruf kapital ke arah vertikal.

Keberadaan agen hayati FMA dan MHB pada budidaya sayuran sistem hidroponik memberikan manfaat dalam pemenuhan nutrisi. Pengaruh konsentasi P 0 ppm mem- berikan pengaruh signifikan terhadap serapan $\mathrm{P}$ pada tanaman selada merah ber-mikoriza. Konsentrasi P 20 ppm menunjukkan pengaruh signifikan terhadap serapan $\mathrm{P}$ pada tanaman 
kangkung non mikoriza dan kangkung bermikoriza. Sedangkan pada konsentrasi P 40 ppm selada merah bermikoriza berbeda nyata terhadap serapan $P$.

Konsentrasi P 80 ppm menunjukkan tidak terdapat pengaruh signifikan terdapat serapan P. Kehadiran FMA bermanfaat bagi tanaman terutama dalam memfasilitasi nutrisi seperti fosfor, seng, tembaga, kalium, kalsium, dan membantu tanaman dalam penyerapan nutrisi dari daerah konsentrasi rendah pada akar (Sharma et al., 2017).

\subsection{Bobot Segar Tanaman}

Hasil pengukuran bobot segar tanaman sayuran dengan perlakuan pengaruh konsentrasi fosfor (P) pada beberapa tanaman sayuran bermikoriza dan non mikoriza disajikan pada Gambar 1. Bobot segar tanaman selada romain non mikoriza pada konsentrasi P 80 ppm menunjukkan bobot segar tanaman paling tinggi. Bobot segar tanaman selada romain bermikoriza pada konsentrasi $\mathrm{P} 40$ ppm memberikan bobot segar paling tinggi dibandingkan perlakuan lainnya. Sedangkan pada selada non mikoriza dan selada merah bermikoriza bobot segar tanaman ditunjukkan pada konsentrasi P 80 ppm. Pada tanaman kangkung non mikoriza bobot segar tertinggi ditunjukkan pada konsentrasi P $40 \mathrm{ppm}$. Bobot segar tanaman kangkung bermikoriza memiliki bobot segar tertinggi pada konsentrasi P 80 ppm.

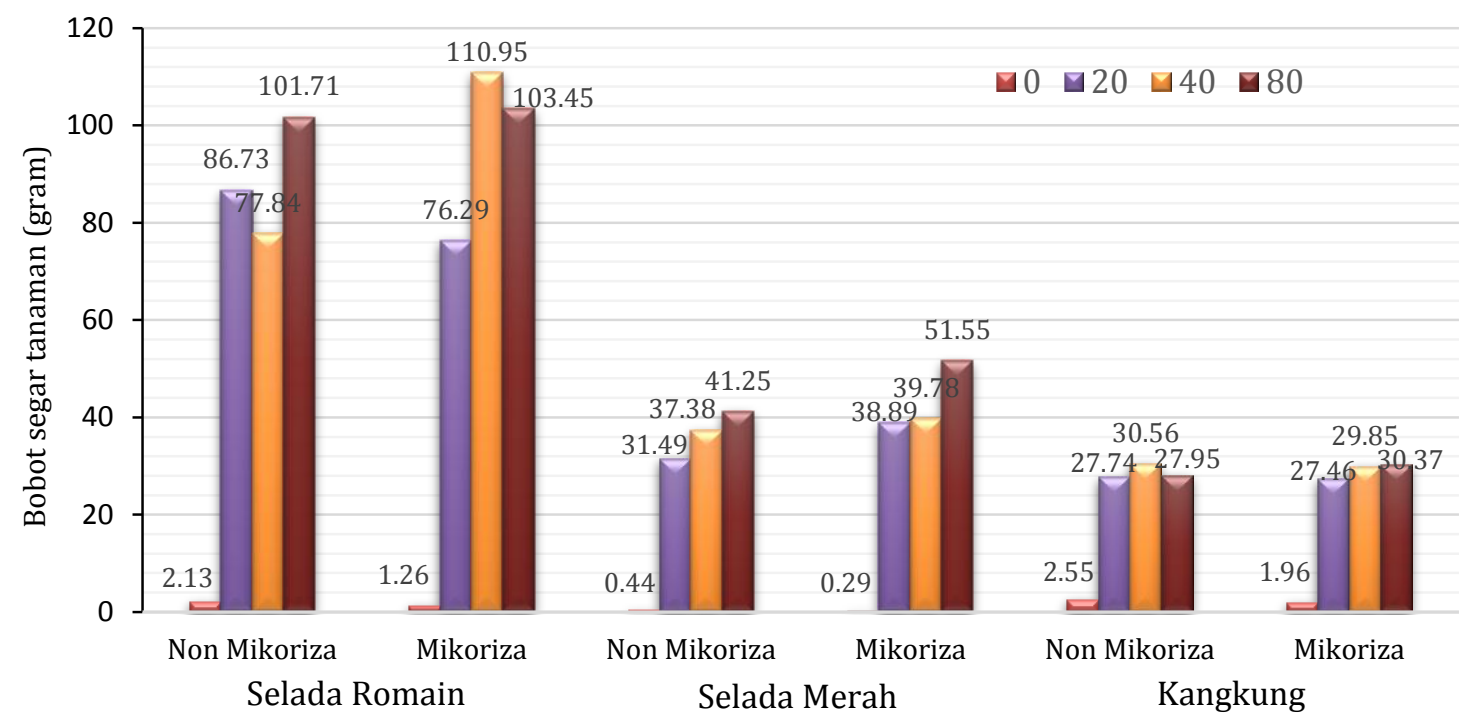

Gambar 1 Rata-rata Bobot Segar Tanaman

\section{KESIMPULAN}

Terdapat interaksi FMA yang berpengaruh positif meningkatkan kolonisasi akar, serapan hara $\mathrm{P}$ terhadap berbagai tanaman sayuran dan berbagai konsentrasi fosfor terhadap pada hidroponik Sistem Ebb-Flow. Aplikasi FMA menurunkan $\mathrm{P}$ pada budidaya sayuran sistem hidroponik model Ebb-Flow. Konsentrasi P pada tanaman selada romain bermikoriza dapat diturunkan menjadi 40 ppm P (50\% dosis P). Konsentrasi $\mathrm{P}$ pada tanaman selada merah bermikoriza dapat diturunkan menjadi 0 ppm P. Konsentrasi $P$ pada tanaman kangkung bermikoriza dapat diturunkan menjadi 20 ppm P (25\%).

\section{DAFTARPUSTAKA}

Barea, J.M. 2000. Rhizosphere and mycorrhiza of field crops. In Toutant et. al. (eds). Biological Resource Management: Connecting Science and Policy (OECD). 
Berlin: INRA, Editions and Springer. $\mathrm{p}$ $110-125$.

Beladinna, H. K. 2017. Produksi Inokulum Fungi Mikoriza Arbuskula Dengan Inang Serai Wangi (Cymbopogon nardus L.) Pada Sistem Hidroponik. Institut Pertanian Bogor. Skripsi.

Edi, S. 2014. Pengaruh pemberian pupuk organik terhadap pertumbuhan dan hasil tanaman kangkung darat (Ipomea reptans Poir). Bioplantae, 3(1): 17-24.

Haryono. 2009. Bertanam Kangkung Raksasa di Pekarangan Rumah. Kanisius. Yogyakarta.

Lee, S. dan Lee, J. 2015. Beneficial bacteria and fungi in hydroponic systems: types and characteristics of hydroponic food production methods. Scientia Horticulturae, 195: 206-215.

Natalia, C., Y. Kusumarini, J.F. Poillot. 2017. Perancangan Interior Fasilitas Edukasi Hidroponik di Surabaya. Jurnal INTRA, 5(2), 97-106.

Novriani. 2014. Respon tanaman selada (Lactuca sativa L) terhadap pemberian pupuk organik cair asal sampah organik pasar. Klorofil, 9(2): 57-61.

Prafithriasari, M. dan A. Nurbaity. 2010. Inefektivitas inokulan Glomus sp. dan Gigaspora sp. pada berbagai komposisi media zeolite-arang sekam dan pengaruhnya terhadap pertumbuhan sorgum (Sorgum bicolor). Jurnal Agrikultura 21(1): 39 - 45.

Sharma, S., Sharma, S., Aggarwal, A., Sharma, V., Singh, M. J., \& Kaushik, S. 2017. Mass multiplication of arbuscular mycorrhizal fungi. In Aggarwal, A and Yadav, K (Eds). Mycorrhizal Fungi. Astral International, New Delhi. p 157-172. 